\title{
直接アゾ染料とスチルベン系ケイ光増白剂の 水溶液および綿布上での光退色相互作用*1
}

\author{
熊本女子大学生活科学部 矢上一夫 \\ 熊本大学工学部山田仁穗・正泉寺秀人
}

\section{PHOTOFADING INTERACTION BETWEEN FLUORESCENT BRIGHTENING AGENT OF A STILBENE TYPE AND DIRECT AZO DYE IN THE AQUEOUS SOLUTION AND ON COTTON*1}

\author{
By Kazuo Yagami ${ }^{* 2}$, Kimiho Yamada*3 and Hideto Shosenji ${ }^{* 3}$ \\ *2 (Department of Science of Living Environment, Faculty of \\ Science of Living, Kumamoto Women's University; Mizuarai, \\ Kengun-machi, Kumamoto City 862 Japan) \\ *3 (Department of Synthetic Chemistry, Faculty of Engineering, \\ Kumamoto University; Kurokami, Kumamoto City 860 Japan)
}

A fluorescent brightening agent of a stilbene type C.I. FBA $24\left(F_{B N}\right)$ was found to enhance the fading rate of a blue direct azo dye C.. . (DB15) in aqueous solution, on the irradiation with a high pressure mercury lamp. On the other hand, DB15 depressed the fading of $F_{B N}$. Fading of both DB15 and $F_{B N}$ was depressed in aqueous solution by the irradiation using a low mercury lamp. Similar effect was also observed in the measurement on cotton fabric, on the irradiation with a high pressure mercury lamp, whereas $F_{\mathrm{BN}}$ depressed the fading of the dye on the irradiation with a low pressure mercury lamp. These effects were found in the concentration range of the dye bath of $F_{B N}$ higher than $1 \times 10^{-5} \mathrm{~mol} / \mathrm{l}$. The dye accelerated the fading of $F_{\mathrm{BN}}$ at the early stage of the reaction when exposed to a low pressure mercury lamp, a high pressure mercury lamp or a xenon lamp.

(Received October 19, 1981)

\section{1. 緒 言}

色素湜合系で色素の光退色が増感される現象はCatalytic fading として染色工業上重要な問題とされている゙ー我々はこれまでアゾ系色素, 泫, トリフェニルメタン系色 素”，アントラキノン系色素门 の光退色をスチルベン系 あるいはピラン゙リン系ケイ光增白剤が促進す石事実を認

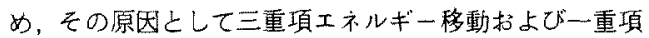
酸盝の寄与を指摘した。本研究ではスチルベン系ケイ光 增白剂上直接アゾ染料の光退色相互作用を水溶液でくわ しく調べるとともに，奏際的問題として綿布上での光反

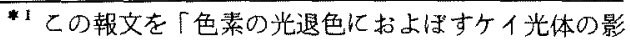
響(第 5 報)， The effects of fluorescent substances on the photofading of colors (Part 5)」 とする。

応について検討した。

\section{2. 実験}

2.1 化合物

色素としてとりあげたベンジジン柔直接ア・゙染料Direct Sky Blue 5B(C.I.Direct Blue 15，以下DB15 と略 記する)括よびケイ光增白剂としてとりあげた直接染料

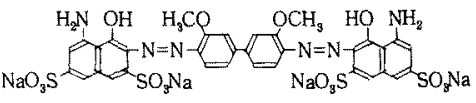
DB 15

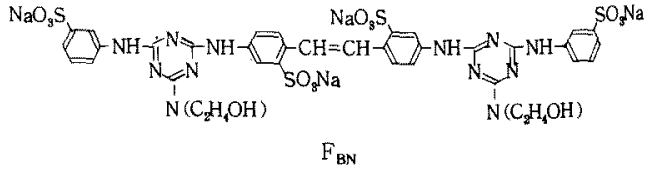


型スチルベン系ケ代光增白剂Mikephor BN(C. I. FBA

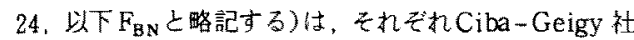
招よび三井東圧化学工業 (株) 製品を Robinson-Mills法 毛しくはエタノールからの再結晶により精製し，薄層ク ロマトグラフィで一点スポットを与えることを確認した。 DB150純度はチタン分析法により96.4\%で市る。

\section{2 染 色}

未さらし木綿プロード(タテ、ヨコ系ともに40/1)を 常法によりノリ报き，精練，漂白し，さらに30\%ピリシ ン水溶液で $60 \mathrm{C} ， 20$ 分起理した後，水洗，乾燥した。 との綿布を色素の $1 \times 10^{-7} \sim 5 \times 10^{-4} \mathrm{~mol} / \mathrm{l}$ 濃度溶液 用いて浴比 1：100，90 C，60 分で染色した。染色には 中央理化器製作所製 U- 12 型水平振之う式染色機( ス卜 ローク $4 \mathrm{~cm}, 120 \mathrm{spm}$ )を使用した。ケイ光增白剂は1 $\times 10^{-6} \sim 1 \times 10^{-3} \mathrm{~mol} / l$ 濃度溶液用いて浴比 $1 ： 100$ ， $40 \mathrm{C} ， 20$ 分で同様仪增白处理した。っいでこれらの染

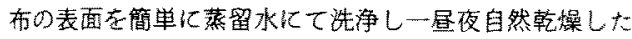
のち相対湿度 $65 \%$ のデシケーター中に保存した。

\section{3 光退色実験}

\subsection{1 水溶液}

色菜は $1 \times 10^{-5} \mathrm{~mol} / l$ ，ケイ光增白㓮は $1 \times 10^{-6} \sim 3 \times$ $10^{-5} \mathrm{~mol} / l$ 濃度にて空気飽和条件下 30 Cでリリゴー ラシンド方式で光照射した。光源としては $6 \mathrm{~W}$ 低王水銀 奵あるいはハイレックスフィルターを備えた 100 W高王 水銀灯老用いた。前者は主として $253 \mathrm{~nm}$ 光を，また後 者は $300 \mathrm{~nm}$ より長波長の光を発する。試料溶液は日立 自記分光光度計EPS - IIU型で紫外・可視吸収スペクト ルを測定し，乙机に $\mathrm{G}-3$ 型ケイ光分光付属装置をとり つけてケイ光スペクトルを洌定した。

\subsection{2 染 布}

染布は17 27Cにて水溶液の場合上同様化光照射した。 さらに染布の場合は $1.5 \mathrm{~kW}$ ギンランプとパイレック スフィルターを備えた東洋理化工業(株)製フメードメー ターを用いて, 温度 $63 \pm 3{ }^{\circ} \mathrm{C}$, 相対湿度 $65 \pm 5$ \%で全波 長照射した。炤射試料は皘分球付属菩置を備えた島津 UV-200自記分光光度計考用いて反射スペクトルを测定 し、島津デシタル分光ケイ光光度計DF-510 型记固体試 料木ルダーをとりつけ励起波長 $365 \mathrm{~nm}$ ，ケイ光波長 435 nmでケイ光强度を测定した。

\section{3. 結果と考察}

\section{1 水溶液}

色素书よびヶイ光增白剂の水溶液での紫外・可視吸収 スベクトルを図1に示す。図1にはケイ光增白剂のケイ 光スペクトルすあわせて示す。色菜・ケイ光增白㓮混合 系の吸収スペクトルは成分の単なる重如合わせとして理

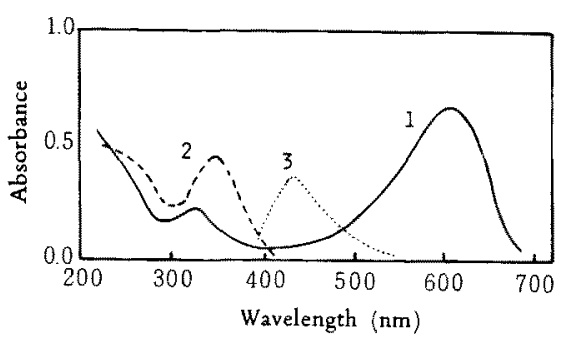

Fig. 1. Absorption spectra of DB15 (1) and $F_{B N}$ (2), and the fluorescence spectrum of $F_{B N}$ (3) in aqueous solutions.

Concentration: $10^{-5} \mathrm{~mol} / \mathrm{l}$.

The fluorescence spectrum gives relative intensity.

解できた。光照射により色素の可視部吸收帯は単調に減

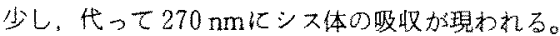

ケイ光增白剂の光照射に上る变化をみる目的でケイ光 強度の時間变化調へ，その初期值との此图 2 にプロ ットした。淌王水銀灯の場合，初期にトランス体加らシ ス体への急速な光異性化 ${ }^{8)}$ が起り，これに比較的遅い二 次的光分解反応加つつく。色素を添加すると、シス体一 の異性化は $36 \%$ 程度抑えられる。これは色素の光吸収に 上り照射光の波長分布が変化するため之理解される。図

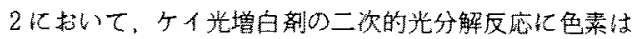
さして影響しないととがわかる。一方低王水銀灯照射の 場合は色素化上りケイ光增白剂の二次的分解反応が多少 抑えられる。すでに報告したように， $\mathrm{F}_{\mathrm{BN}}$ に似た構造の スチルベン采ケイ光增白剤C. I.FBA90 (Mikephor BS)

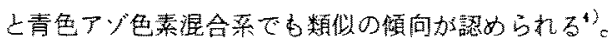
つづいて色素の退色に及ぼす $\mathrm{F}_{\mathrm{BN}}$ の効栔を調べた。色 素の可視部吸収極大での吸光度の減衰加煺色速度定数

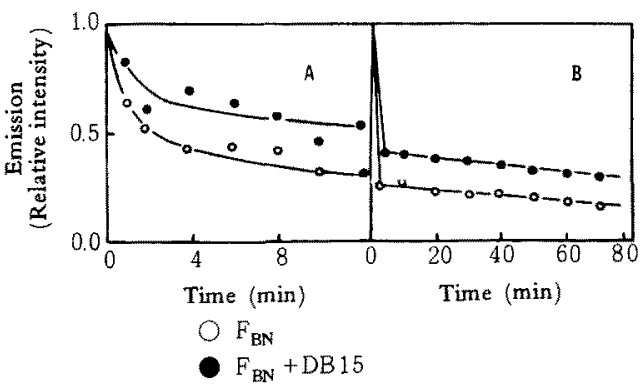

Fig. 2. Fading of fluorescence of $F_{\mathrm{BN}}$ in aqueous solution. Concentration: $10^{-5} \mathrm{~mol} / \mathrm{l}$.

Light source: (A) low pressure $\mathrm{Hg}$ lamp; (B) High pressure $\mathrm{Hg}$ lamp equipped with a Pyrex filter. 


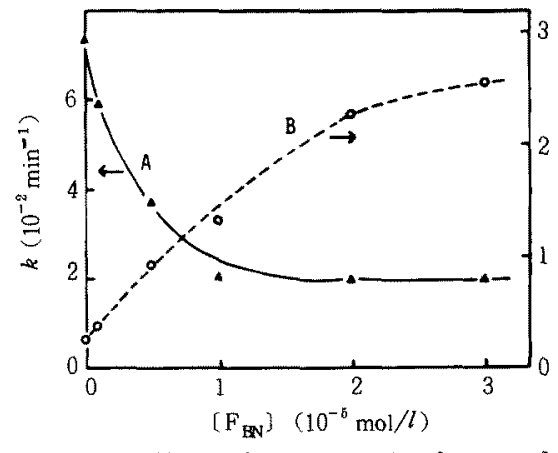

Fig. 3. The effect of $F_{B N}$ on the fading of rate constant of DB15 in aqueous solution. Concentration of DB15: $10^{-5} \mathrm{~mol} / \mathrm{l}$.

$A$ and $B$ indicate the same light source as in Fig. 2.

を求め，その反応初期䛧をケイ光增白剂の濃度に対して プロットする之図3加得られる。すで代我々はスチルベ 孫ケイ光增白剂Mikephor BS およびピラゾリン系ケ 1光增白剂C.I.FBA 54 (Tinopal WG) が 300 400nm 光照射にて青色アゾ色素の水溶液での光退色を著しく促 進する事実を報告しだ”。今回の $\mathrm{F}_{\mathrm{BN}}-\mathrm{DB} 15$ 混合系化 高圧水銀灯照射した場合も，ケイ光增白剂に上る色素の 退色促進がみら机る。我々はこれまでピラン゙リン系ケイ 光增白剂之種々の色素の光退色相互作用を検討して，退

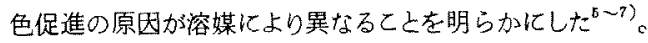
すなわら水あるいはメタノールなどー重項酸素の寿命の 短い溶媒中では三重項エネルギー移動が，アセ卜ニトリ ルのように一重項酸素の寿命の長い溶媒中では一重項酸 素が光退色相互作用の原因之若えられる。今回の $\mathrm{F}_{\mathrm{BN}}$ の 場合も水溶液での反応を問題としているので三重項エネ ルギー移動が主要な寄与をなすすのと推定される。図2 にてケイ光增白剂の演度上已もに退色促進の度合いは增 すが，高濃度側では增加は頭打ちとなる。乙れは $\mathrm{F}_{\mathrm{BN}}$ 濃 度か $2 \times 10^{-6} \mathrm{~mol} / \mathrm{l}$ のときず隹高生水銀灯の主輝線波 長 $366 \mathrm{~nm}$ 付近で溶液の透過率が約 $10 \%$ 上なり，濃度を 增しても吸収光量は一定值化近つくくためである。低圧水 銀灯照射下では色素は単独で退色速度が大きいが，ケイ 光增白剂を添加すると退色は㧕制される。これはケイ光 堌白剂の紫外線しゃへい効果に上るものと考えられるが， 抑制の度合は $1 \times 10^{-5} \mathrm{~mol} / /$ 以上で一定となること加ら， ケイ光增白剂は色素に一部退色促進効果も及㳻している と推定される。

\section{2 木綿染布}

木綿染布の反射スペクトルを図4亿示す。色素は 620 $\mathrm{nm}$ に吸収極大を示す。種々の染浴濃度で染色した綿布 の $620 \mathrm{~nm}$ での反射率 $R$ を Kubelka-Munk $の$ 式 $^{\text {9) }}$

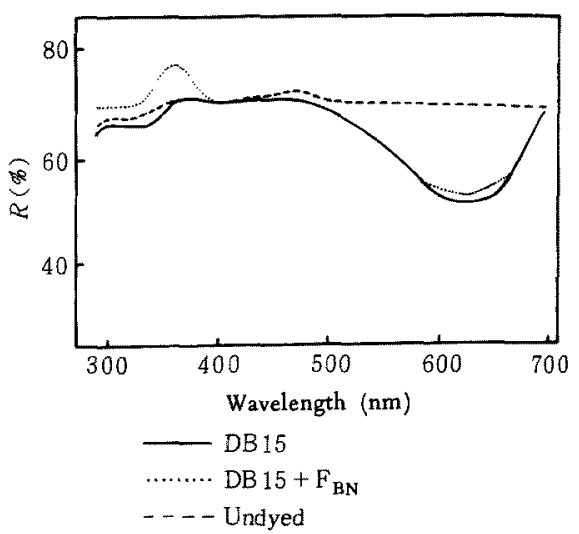

Fig. 4. Reflection spectra of cotton treated with $\mathrm{DB} 15$ and $\mathrm{F}_{\mathrm{BN}}$.

Concentration of $\mathrm{DB} 15$ and $\mathrm{F}_{\mathrm{BN}}$ in the dye bath are both $10^{-5} \mathrm{~mol} / \mathrm{l}$.

$$
f=\frac{(1-R)^{2}}{2 R}
$$

に適用したところ $5 \times 10^{-4} \mathrm{~mol} / \mathrm{l}$ 以下で染浴濃度と $f$ と の間䎲直線関係が成立した。よって以後の実験では色兹 の染浴濃度を $5 \times 10^{-5} \mathrm{~mol} / \mathrm{l}$ に統一した。一方ケイ光增 白剂は図 4 にて $360 \mathrm{~nm}$ に反射極大を示している。励起 波長 $315 \mathrm{~nm}$ ，ケイ光波長 $435 \mathrm{~nm}$ にてケイ光強度を溳定 すると， $F_{\mathrm{BN}}$ 染浴濃度との間に相関関係が認められ, と くに $4 \times 10^{-6} \mathrm{~mol} / l$ 以下ではケイ光強度は染浴濃度に比 例して增加した。

高圧於よび低王水銀灯照射下での色素の退色曲線を四 5 亿示す。高王水銀灯炤射下ではケイ光増白剂は色菜の 退色を初段階で促進する。Giles と Rahmanはセロフ ンフィルムでケイ光增白戍C.I.FBA 15，17 あるいは18 がアゾ色素C.I.Direct Red 2 むるいは23の耐光性を低 下させることを認めた ”。また 亿光增白剂 Tinopal BVとLumisol BB がバット染料C, I.Vat Orange 2 とC.I.Vat Yellow $2 の$ 退色綿布上 で促進すると報告している゙）今回の綿布でも類似の結 果か得られた。前述の上うにケイ光增白剂は水溶液で色 素の退色を促進し，その原因として三重項エネルギー移 動が推定される。一方Rembold と Kramer はエチルセ ルロースフィルムでアントラキノン色素とアゾ色菜の光 僈色相互作用を調べ，一重項酸素の役割を指摘した ${ }^{3\rangle}$ 。 我々もセルロースアセテートフィルム上でのピラゾリン 系ケイ光增白剂とアントラキノン系色菜の光退色相互作 用について一重項酸素の寄与を推定した ${ }^{7}$ 。今回の綿布 上の光反応に㧍ける相互作用の原因解明は今後の課題で ある。図 5 にて炤射時間約 6 時間以後はケイ光增白剂俎 


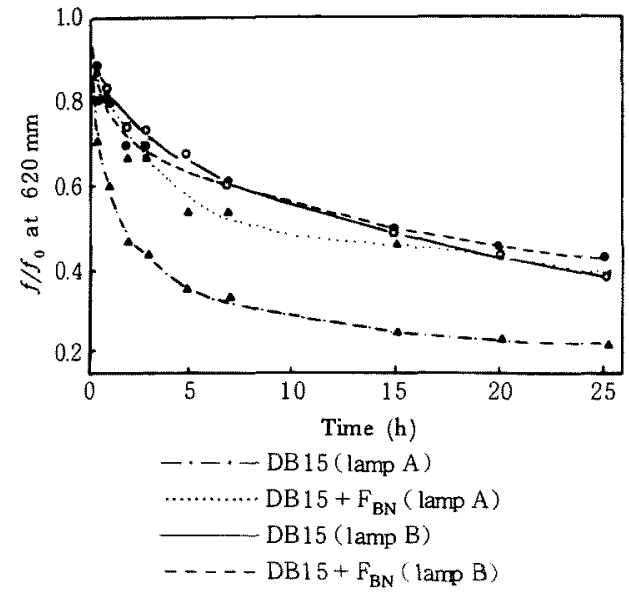

Fig. 5. Fading curve of DB15 on cotton in the presence of $\mathrm{F}_{\mathrm{BN}}$.

Dye bath concentration: $5 \times 10^{-5} \mathrm{~mol} / 1$ (DB15), $10^{-3} \mathrm{~mol} / 1\left(\mathrm{~F}_{\mathrm{BN}}\right), f$ is given by eq. (1); $f_{o}$ is the initial value of $f ; \operatorname{lamp} \mathrm{A}$ and B: $c f$. Fig. 2.

理布の方が末処理布より色素の退色はやや遅い。後述の ケイ光強度の測定加ら，照射 6 時間でケイ光增白戍は 70 多変化していると推定されるので，色素の退色揤制はケ イ光增白剂の退色生成物か関係している可能性が大きい。 低生水銀灯照射の場合は色菜はヶイ光增白剂に上り退色 が抑制される。これ水溶液と同様尔光增白剂心紫外 線しゃへい効果加原因と考えられる。

退色曲線加ら色素の初期退色速度定数求め，ケ侊 增白剂の染浴澧度に対してプロットすると図 6 が得られ る。明ら加汇約 $10^{-5} \mathrm{~mol} / l$ 以上で $\mathrm{F}_{\mathrm{BN}}$ の染浴濃度とと

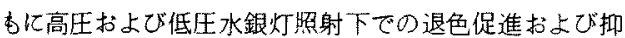

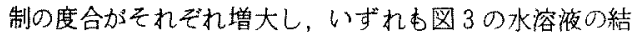
果之似た煩向が琶められる。図6にはキセノン灯照射の

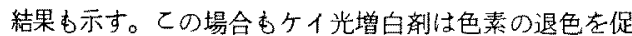
進するが，その程度は高生水銀灯の場合よりやや小さい。 キ七ノン灯では高王水銀灯の波長域のみならず，短波長 側の波長分布古作用して，低圧水銀灯でみら机るケイ光 增白剤偟よる抑制勃果が加わるためである。

表1にケイ说增白剤のケイ光强度の減少率を示す。各 光源を通じて，反応初期に扑いては色素はケイ光增白剂 の退色を促進している。ただしこの効果がケイ光增白剂 のトランスーシス異性化任関保するか，あるいは二次的 光分解反応比関倸するか不明である。照射が 20 時間を こえると逆に色素がケイ光增白㓮の退色を㧕制する。え の度合は低压水銀灯に执いて著しいが，長時間照射の祭 は試料染布の水分変化その他の要团が反応汇影響する之

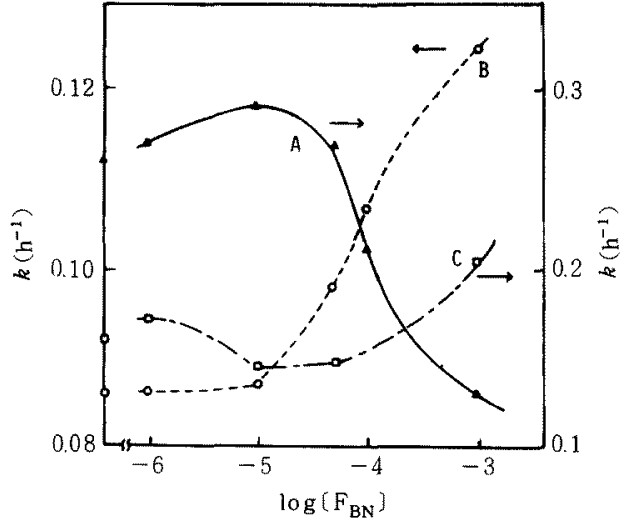

Fig. 6. Plots of the fading rate constants of DB15 on cotton against the logarithm of dye bath concentration of $F_{B N}$.

$\left[\mathrm{F}_{\mathrm{BN}}\right]$ is given by in $\mathrm{mol} / \mathrm{l}$; dye bath concentration of DB15: $5 \times 10^{-5} \mathrm{~mol} / \mathrm{l}$.

$A$ and $B$ indicate the same light sources as in Fig. 2; C: Xe lamp equipped with a Pyrex filter.

Table 1 Photo-decay of fluorescence of $F_{B N}$ on cotton ${ }^{2}$

\begin{tabular}{ccccc}
\hline Additive & Time $(\mathrm{h})$ & $x_{\mathrm{A}}$ & $x_{\mathrm{B}}$ & $x_{\mathrm{C}}$ \\
\hline None & 2 & 46 & 21 & 73 \\
None & 25 & 91 & 89 & 98 \\
DB15 & 2 & 50 & 30 & 78 \\
DB15 & 25 & 85 & 90 & 97 \\
\hline
\end{tabular}

$x_{\mathrm{A}}, x_{\mathrm{B}}$ and $x_{\mathrm{C}}$ denote the percent decay of the intensity of fluorescence caused by the irradiation with the lamp A, B and C, respectively; $c f$. Fig. 2 and 6 .

a. Dye bath concentration: $1 \times 10^{-5} \mathrm{~mol} / 1\left(\mathrm{~F}_{\mathrm{BN}}\right)$, $5 \times 10^{-5} \mathrm{~mol} / 1$ (DB15).

推定されなお捡討を必要とする。

付記：本研究の一部は第 23 回染色化学討論会(昭和 56 年 6 月，東京)にて発表した。本研究に当り実験什協 力された内田光則，坂口さ中り，丹波資澄、野口尚子の 諸氏に感謝の意を表する。

\section{文献}

1) C. H. Giles, S. M. K. Rahman, J. Soc. Dyers Colour., 76, 681 (1960).

2) W.B. Achwal, R.B. Chavan, Indian J. Technol., 8, 15 (1970).

3) M. W. Rembold, H. E. A. Kramer, J. Soc. Dyers Colour., 94, 12 (1978).

4) 山田㯖，正泉寺秀人，内田光則，五十禹 博、日 化， $1974 ， 563$ 
5）正泉寺秀人，五十阖 博，山田仁穗，日化，1978， 271.

6) K. Yamada, H. Shosenji, Y. Nakano, M. Uemura, S. Uto, M. Fukushima, Dyes and
Pigments, 2, 21 (1981).

7) W. T. Weller, J, Soc. Dyers Colour., 95, 187 (1979).

8) 福田 保、染色工業，12，461 (1964). 